\title{
今 世界の医療は?
}

石塚 尋朗 小野 広一 吉田直之 川村 光信 宇野 久光

Key words : vitamin $\mathrm{K}$ for warfarin, lipid-lowering therapy, myocardial infarction, off-label medication, alcohol use, natriuretic peptide, aspirin and clopidogrel, nursing home physicians, methadone, aspirin for cardiovascular disease, drug-resistant tuberculosis

[日内会誌 $98: 1429 \sim 1434,2009$ ]

最新の医学, 医療のトピックスが掲載された 米国内科学会 (ACP) 雑誌 (Annals of Internal Medicine) の目次と要旨 (抜粋) を ACP日本支 部Publication Committee委員が日本語訳し， ACP日本支部のホームページに掲載しています. 医学, 医療の新たな情報を把握するのに有用で す. URL : http://acpjc.naika.or.jp

\section{Annals of Internal Medicine紹介} 3 March 2009 Volume 150 Issue 5

\section{原著（Articles）}

ワーファリン服用患者での過剩な抗凝固状態の 是正に対する経ロビタミンK療法とプラセボの比 較：無作為化試験

Oral vitamin $\mathrm{K}$ versus placebo to correct excessive anticoagulation in patients receiving warfarin : a randomized trial.

Mark A. Crowther, et al.

Crowtherと同僚らは, ワーファリンを服用し ていて，国際標準比 (INR) 4.5〜10.0の 724 人の 患者で, 経口ビタミン $\mathrm{K}$ とプラセボの出血予防効 果を検討した. ビタミンK投与群の $15.8 \%$, プラ セボ投与群の $16.3 \%$ が少なくとも 1 回の出血性

いしづかじんろう，おのこういち，よしだ なおゆき，かわむら みつのぶ，うの ひさみつ：専 門医部会
合併症を経験し，重大な出血性イベントがそれ ぞれ $2.5 \%, 1.1 \%$, 血栓塞栓症が $1.1 \%, 0.8 \%$ に 生じた. 低用量の経口ビタミンKはINRを低下さ せたが，過剩な抗凝固状態にある患者の出血を 減少させなかった。

HIV 感染, 非感染患者の新規脂質低下療法への反 応

Response to newly prescribed lipid-lowering therapy in patients with and without HIV infection. Michael J. Silverberg, et al.

Silverberg と同僚らは, 829 名の抗レトロウイ ルス療法を受けているHIV (human immunodeficiency virus) 感染患者と 6,941 名のHIV非感染 患者において脂質低下療法の効果と安全性につ いて比較した。低比重リポ蛋白コレステロール と中性脂肪レベルの低下の程度は, 非感染者に 比べてHIV感染者ではより低かった. 中性脂肪に 対するゲムフィブロジルの効果は, 低比重リポ 蛋白コレステロールに対するスタチンの効果よ り大きかった. 脂質異常症は, 一般人と比べHIV 感染者においては, 治療がより困難である.

心筋梗塞のアウトカムにおける人種差に関連す る因子

Factors associated with racial differences in myocardial infarction outcomes. 
John A. Spertus, et al.

心筋梗塞に罹患した 1,849 名のアメリカ人患者 の $28 \%$ は黒人で, 未調整の死亡率と再入院率が より高く, 狭心症がより多く, クオリティ・オ ブ・ライフ（QOL）がより低かった。しかしな がら，患者の危険因子やケアを受けている施設 などが白人と黒人で同程度であるように統計学 的に調整すると，これらの差違の多くはみられ なくなった。これらの結果から，心臓病のベー スラインリスクや入院に関わる因子の差異は, 心筋梗塞のために受けた治療の差異に比べて, より重要なアウトカムの決定要因であることが 示唆される.

\section{患者診療の質の改善 (Improving Patient Care)}

患者と医師の ‘つながり度’ とプライマリ・ケ アの質

Patient-physician connectedness and quality of primary care. Steven J. Atlas, et al.

‘つな゙り度” (患者が特定の医師あるいは医療 機関で診察を受けているか否か) が，臨床能力 の指標におよぼす影響については明らかでない. 最近妥当性が検証された指標を用いて，著者ら はプライマリ・ケア医と ‘つながり’がより強 い患者は，推奨されている予防サービスを受け る頻度がより高いことを見出した。本論文で示 された患者と医師の ‘つながり度’の評価法は, プライマリ・ケアにおける患者中心のメディカ ル・ホームモデル支持のよい指標になるかもし れない.

\section{総説（Reviews）}

系統的レビュー：腫瘍領域での適応外使用にお ける医薬品集の信頼性

Systematic review : reliability of compendia methods for off-label oncology indications.

Amy P. Abernethy, et al.

米国CMS (Center for Medicare \& Medicaid Services）は抗悪性腫瘍薬の適応を医薬品集に登
録されている疾患に限定し, 未認可の疾患に対 しての適応外使用は制限している. 14 の適応外 使用の系統的レビューで, 6 つの医薬品集が総合 的かつ研究に基づいた, 時期を得た情報を提供 しているかを評価した．現在の医薬品集は透明 性に欠け，エビデンスをまとめ最新のものにす る系統立てた方法に従っておらず, 多くの試験 結果を採用できていないと, 著者らは結論して いる.

\section{展望 (Perspectives)}

\section{医薬品の適応外使用をコントロールする}

Controlling off-label medication use.

\section{Muriel R. Gillick}

薬剤の適応外使用は必要であるが, 毒性, コ スト，有効性についての懸念がある。これをコ ントロールする手段になりうるものは，高額か つ潜在的に危険な薬剤一主にバイオテクノロジー から生まれた薬剤一に重点的に取り組むことで ある。この論文ではそのような薬剤の使用をコ ントロールする二段階のプロセスを提案する.

メディケアのもとでの収載医薬品集と抗悪性腫 瘍薬

Compendia and anticancer therapy under Medicare. Katherine Tillman, et al.

2007 年にCMSは, 医薬品集に収載可能な薬品 のリストを改定するために，公に透明性のある プロセスを確立させた. 利害の衝突の結果, 偏つ た判断に至る可能性があるので, 2008 年の「患 者と供給者のためのメディケア改善法案」の条 項では，編集者やアドバイザーの利害の衝突を 特定し，治療法を評価するための公に透明性の あるプロセスを欠いた医薬品集をCMSが使用す ることを禁じている.

\section{論評 (Editorials)}

かかりつけのドクターはいますか？

Is there a personal doctor in the house? 
Andrew B. Bindman

本号ではAtlasと同僚らが, かかりつけ医がい る患者のほうがプライマリ・ケアの現場で推奨 される予防サービスを受けやすい傾向が高かっ たこと，また患者と医師の ‘つながり度”は医 療機関によって異なることを報告した，著者ら はプライマリ・ケアと患者中心のメディカルホー ムの主要な特徵を評価するための方法を提案し, かつその妥当性を検証することで重要な一歩を 踏み出した，この評価方法は, 管理データのみ を必要としているが, さらに広く検証する価值 がある。

\section{抗悪性腫瘍薬の適応外使用の評価：変更の時}

Evaluating off-label uses of anticancer drugs : time for a change. Harold C. Sox

Abernethyと同僚ら, Gillick, そしてTillman と同僚らによる本号における論文は, 最良のエ ビデンスを臨床に与えようとする私たちの努力 における弱点をあきらかにしている. Tillman と同僚らは, 医薬品集の信頼性について疑問を 投げかけている. Abernethyと同僚らのレビュー を検討するための基礎知識を提供している.

Gillickは強固な意志決定の過程では, 最も高額 で副作用の強い抗悪性腫瘍薬に注意を払うべき だと考えている. エビデンスの系統的レビュー があるCMS国民保険適用の手続きを使うという Gillickらの提案のようなものを我々は採用するべ きであると考える。

（本号の翻訳者：岩永正子, 井田弘明, 吉田 博, 紺谷 真, 沖 将行, 柳 秀高, 桑江紀子, 岩本和也, 岩本和也, 廣井直樹, 永松聡一郎, 川上寿一，以上翻訳順）

\section{March 2009 Volume 150 Issue 6}

\section{原著 (Articles)}

呼吸困難での救急診療部受診患者におけるB型ナ トリウム利尿ペプチド検査, 臨床的アウトカム および, 保健医療の利用 : 無作為化試験

B-type natriuretic peptide testing, clinical outcomes, and health services use in emergency department patients with dyspnea : a randomized trial. Hans-Gerhard Schneider, et al.

B型ナトリウム利尿ペプチド (BNP) 検査は, 呼吸困難が心臓性か非心臓性かを区別するため に広く用いられている.この無作為化試験では, BNP検査は医療サービスの利用を減少させず, 救急部を受診した呼吸困難患者の健康のアウト カムを改善させなかった。すべての呼吸困難患 者に対し, 心不全が症状の原因かどうかを知る ためにBNPを測定することは正当化されないか もしれない.

\section{入院後における生活空間の移動性の軌跡}

Trajectories of life-space mobility after hospitalization. Cynthia J. Brown, et al.

生活空間とは，ある人がどこへ，どれほどの 頻度で, どの程度自立して行けるかを測定する ものである。これは社会的参加の度合いも反映 しているため, 高齢者における身体的機能をよ り正確に測っているかもしれない. Brownと同 僚らは, より高齢の入院患者において, 自己申 告した生活空間が減少していることを報告した. 手術が必要な患者の場合, 他の理由で入院した 人々に比べて, 急激に生活空間が減少するが, その回復はより急速だった.

心血管疾患予防のためのアスピリン：血栓症お よび出血に関するアスピリン投与量とクロピド グレルとの関係

Aspirin to prevent cardiovascular disease: the association of aspirin dose and clopidogrel with thrombosis and bleeding. 
Steven R. Steinhubl, et al.

無作為化比較試験によるデータの多重比較分 析では, 心血管イベント予防に使用するアスピ リンの投与量は, 効果と安全性に影響しないこ とを示唆している．しかしながら，無作為にク ロピドグレルを加えた患者群においては，高用 量のアスピリンは効果を減弱させ有害事象を増 加させるようであった。低用量アスピリン（1 日 $75 \mathrm{mg}$ から $81 \mathrm{mg}$ ) は, 長期の予防にアスピリ ンを必要とする患者, 特にクロピドグレルの服 用患者にとっては最も有効で安全と思われる.

\section{展望 (Perspectives)}

養護老人ホーム専門医：長期における従業員危 機への応答

Nursing home physician specialists:a response to the workforce crisis in long-term care.

Paul R. Katz, et al.

養護老人ホームで勤務する内科医の専門分野 の細分化は, 医学的に複雑な疾病を患う入居者 の全般的なケアの質を脅かす. Katzと同僚らは, 養護老人ホームを特有な実践の場とみなす養護 老人ホーム専門医療を立ち上げることを提案し ている，Katzらは，立体的に，その専門医療を 特徵づけ, ケアの質・健康政策・研究の必要性 の意味を議論している.

\section{診療ガイドライン（Clinical Guidelines）}

\section{メタドン治療時のQTc間隔のスクリーニング}

QTc interval screening in methadone treatment. Mori J. Krantz, et al.

メタゾンの処方は, QT間隔の延長とそれにと もなう torsade de pointesの危険性があり，その 処方に対する安全な勧告を作成するために専門 家から成る委員会が開かれた，委員たちは，臨 床医がメタドンを処方する際，患者に不整脈の リスクについて説明するとともに心疾患の既往 について聴取することを勧告した。 また，患者 に対してメタドンの投与前とフォローアップの
心電図検査を行うことも勧告した。 心拍数で補 正されたQTc間隔が $450 \mathrm{~ms}$ たは $500 \mathrm{~ms} り も$ 延長した場合における可能な対処法として, 患 者とメタドン服用にともなう危険性と有用性に ついて話し合うこと，より頻回に心電図検查を 行うこと，メタドンの投与量を減らすあるいは 投与を中止すること，などを挙げている．つま るところ, 臨床医はメタドンと, QT間隔延長作 用やメタドンの体外排泄遅延作用を持つ他の薬 物との薬物相互作用について学ぶべきである.

心血管疾患予防のためのアスピリン：米国予防 医療サービス専門作業部会からの勧告声明

Aspirin for the prevention of cardiovascular disease:U.S. Preventive Services Task Force recommendation statement.

U.S. Preventive Services Task Force

米国予防医療サービス専門作業部会(USPSTF) は，男性における心筋梗塞や女性における虚血 性脳卒中を減ずる効果が消化管出血のリスクを 上回る場合, 45 歳から 79 歳の男性および 55 歳から 79 歳の女性にアスピリンの使用を推奨す る (推奖度 $\mathrm{A})$ 。これらの年齢より若い男女には 心血管疾患予防のためにアスピリンを使用すべ きではないことを推奨する(推奨度D)。80歳以 上の男女に拈ける，心血管疾患の予防を目的と したアスピリン使用の効果と害を評価するため のエビデンスは不十分である (I statement).

心血管イベントの一次予防のためのアスピリン： 米国予防医療サービス専門作業部会からのエビ デンスの最新情報

Aspirin for the primary prevention of cardiovascular events : an update of the evidence for the U.S. Preventive Services Task Force.

Tracy Wolff, et al.

本号に掲載されている米国予防医療サービス 専門作業部会 (USPSTF)の锥告を支援するため, Wolff 同僚らは心血管疾患の一次予防のための 
アスピリンの功罪についての最新エビデンスを 再評価した。アスピリンは男性の心筋梗塞や女 性の脳卒中発症の危険性を減らすが, 主として 消化管出血イベントを含む重篤な出血イベント の危険性を増やすと, 彼らは結んでいる.

\section{論評 (Editorials)}

心血管疾患の予防と治療におけるアスピリン

Aspirin for prevention and treatment of cardiovascular disease. Shamir R. Mehta

アスピリン使用に関する重要な疑問の解明に 光をあてる二つの研究が, 本号に掲載されてい る. Steinhublと同僚らは, 心血管疾患の予防と 治療におけるアスピリンの最適な投与量を検討 し，投与量を増やすことが，効果の改善につな がらず，出血リスクを高めることに関連するか もしれないことを見出した．冠動脈性心疾患の 一次予防に扔けるアスピリン使用に関する, 最 新のUSPSTFの勧告は, 多忙な臨床医にとって, 重要かつ使いやすい資料である.

\section{まず最初に害のないこと…減量？}

First do no harm ... reduction?

Marc N. Gourevitch

専門家らは,メタドンがQT間隔に及ぼしうる 影響を臨床の場にいかに組み込むかを検討した。 そのうち数名の専門家の研究結果と提唱が, 本 号に掲載されている. 研究者らは, この議論を 呼ぶ領域に足を踏み入れるに際し内科医は, メ タドンの投与を受ける患者すべてにおいて投与 開始前と 30 日後に, そしてその後は 1 年毎に心 電図をとることを提唱している. ガイドライン を実施する前に，ガイドラインとその代わりに なるスクリーニング戦略のどちらを選ぶべきか を決めるために, 代わりのスクリーニング戦略 の代償利益と弊害を明確に評価するための判断 分析のような研究方法が, 採用されるべきであ る.

\section{ACP Journal Club}

患者ヶアのための最良の新しいエビデンス

論評：美しい仮説の中心部に醜い事実を通過 させるにはどうしたらよいですか？

Editorial: what does it take to put an ugly fact through the heart of a beautiful hypothesis?

レビュー：周術期の $\beta$ 遮断薬は非心臓手術を受 ける患者に明らかな利益をもたらさない.

Review : perioperative $\beta$-blockers provide no clear benefit in patients having noncardiac surgery.

レビュー：長時間作用型 $\beta$ 刺激薬は, 吸入ステ ロイドを投与されている患者の喘息関連入院の 危険性を増加しない.

Review:long-acting $\beta$-agonists do not increase risk for asthma-related hospitalization in patients taking inhaled corticosteroids.

レビュー：慢性閉塞性肺疾患において吸入ス テロイドは死亡率を減少させないが, 肺炎を増 加させる.

Review : inhaled corticosteroids do not reduce mortality but increase pneumonia in chronic obstructive pulmonary disease.

レビュー：口腔衛生の促進は病院, 老人ホー ムでの高齢者の呼吸器感染症を予防する.

Review : enhanced oral hygiene prevents respiratory infection in older persons in hospitals and nursing homes.

厳格な血糖コントロールと標準的なコントロー ルとで，コントロール不良の 2 型糖尿病患者に おける主要な心血管イベントあるいは死亡数に 差異がなかった.

Intensive and standard glucose control did not differ for major $\mathrm{CV}$ events or death in poorly controlled type 2 diabetes.

葉酸とビタミンB6, B12 の併用療法は, 心血 管疾患のハイリスク群の女性における癌のリス クに影響を与えなかった。

Combined therapy with folic acid and vita- 
mins $\mathrm{B} 6$ and $\mathrm{B} 12$ did not affect cancer risk in women at high risk for $\mathrm{CV}$ disease.

セレニウム, ビタミンEは, 単独あるいは併用 で前立腺癌を予防しなかった。

Selenium and vitamin E, alone or together, did not prevent prostate cancer.

ビタミン $\mathrm{E}$, ビタミンCは, 単独あるいは併用 で男性の前立腺あるいは全ての癌を予防しなかっ た。

Vitamin E and vitamin C, alone or together, did not prevent prostate or total cancer in men.

バラシクロビルではなくプレドニゾロンは, ベル麻瘏の顔面神経機能の完全回復までの時間 を短縮させた.

Prednisolone, but not valacyclovir, reduced time to complete recovery of facial-nerve function in Bell palsy.

レビュー：過敏性腸症候群の診断において, 臨床所見の組み合わせは中等度の感度と特異度 を示した。
Review : combinations of clinical findings had moderate sensitivity and specificity for diagnosing the irritable bowel syndrome.

男性において, Reynoldsリスクスコアは伝統 的な危険因子のみよりも, より正確に心血管イ ベントを予測した.

Reynolds Risk Score for men predicted cardiovascular events more accurately than traditional risk factors only.

改訂Genevaスコアの簡素化は肺塞栓症の診断 の正確性を減じることはなかった。

Simplification of the revised Geneva score did not decrease accuracy for diagnosis of pulmonary embolism.

（本号の翻訳者：土屋直隆, 板東 浩, 柳川 健, 市堰 肇, 田村功一, 浦野哲哉, 山前正臣, 山内高弘, 菊地基雄, 植田秀樹, 䦎 康博, 以 上翻訳順） 